\title{
Hoplias aff. malabaricus Bloch, 1794 (Characiformes: Erythrinidae) parasites
}

\section{Parasitos de Hoplias aff. malabaricus Bloch, 1794 (Characiformes: Erythrinidae) \\ Thássia Reis" ${ }^{\text {* }}$, Helcileia Santos ${ }^{1}$, Sílvia Barbosa', Taiã Peixoto', Viviane Maruo', Fernando Paiva², Marcello Sato'}

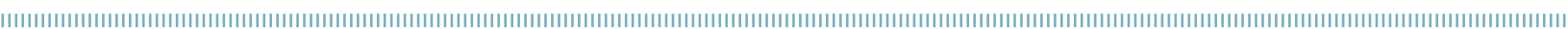

\begin{abstract}
Aquatic organisms are a subject of great interest because of their nutritional value and their high availability as human food. As a result, an increasing number of studies are being conducted on potentially harmful aquatic organisms such as aquatic parasites that compromise host health, as well as affect public health by zoonosis. A balance between the characteristics of healthy and diseased states in fish infected by parasitic fauna is dependent on parasite-host-environment interactions. Here, we have compiled a bibliographical review of the general aspects and epidemiology of the parasites of Hoplias aff. malabaricus Bloch, 1794, a widely distributed and consumed fish species in Brazil.
\end{abstract}

KEYWORDS: helminths; review; trahira; Brazil.
RESUMO: Os organismos aquáticos têm sido alvo de constante interesse por conta de suas características nutricionais e da crescente disponibilização na alimentação humana. Sendo assim, estudos relacionados a organismos nocivos presentes nos ecossistemas aquáticos têm se intensificado, como, por exemplo, acerca dos parasitos, que podem interessar à saúde pública como zoonose ou comprometer a higidez dos hospedeiros. Os peixes apresentam sua fauna parasitária característica em que o equilíbrio do estado saúde-doença é dependente da interaçáo da tríade parasito-hospedeiro-ambiente. Com isso, o objetivo do presente trabalho foi fazer uma revisão bibliográfica de aspectos gerais e da epidemiologia dos parasitos de Hoplias aff. malabaricus Bloch, 1794, amplamente distribuído e consumido no Brasil.

PALAVRAS-CHAVE: helmintos; revisão; traíra; Brasil. 
The trahira, Hoplias aff. malabaricus Bloch, 1794 (Characiformes: Erythrinidae), is a fish well adapted to lentic environments. It has a broad head in the posterior portion, a dilated mouth with strong teeth, a cylindrical and elongated body with a slight lateral compression and covered in oval scales (NOVAES; CARVALHO, 2011).

Trahira has good carcass yield, high meat quality, and is the target species for commercialization. Therefore, it has a huge impact on the economy and public health (ALMEIDA, 1998).

Trahira is an agile, ravenous predator that preys on wide range of fish species (MONTENEGRO et al., 2013). This characteristic of its predation creates favorable conditions for the permanence and dissemination of parasites in the aquatic environment (BARROS et al., 2007).

Health surveillance agencies have observed that parasitic zoonoses are transmitted by consuming raw or undercooked fish. Therefore, this species can cause diseases in humans, creating a huge risk to public health if consumed raw or undercooked (LLAGUNO et al., 2008).

In sweet fish, the main zoonotic helminths found are Eustrongylides sp. (Dioctophymidae) and Contracaecum sp. (Anisakidae) (LUQUE, 2004).

Worldwide, humans have been accidentally infected with helminths found in fish, such as nematodes of the Anisakis species (KIM et al., 2006) and Diphyllobothrium latum, a cestode found in sweet fish or marine fish species that migrate to freshwater for breeding, having bear and man as the definitive hosts. The adult parasite is found in the small intestine of humans, and the eggs are released through the feces, five to six weeks post infection. Exposure to these eggs causes severe lesions and diseases with variable pathogenesis (SAMPAIO et al., 2005; EMMEL et al., 2006).

It is thought the introduction of zoonotic parasites in Brazil is by the import of salmon meat for consumption in oriental dishes (SANTOS; FARO, 2005).

Parasites of the phylum Nematoda (Rudolphi, 1808), that infect fish, exhibit considerable sexual dimorphism and are dioecious, with an indirect evolutionary cycle and planktonic copepods as the intermediate hosts (LUQUE, 2004).

CORRÊA et al. (2013a) identified larvae of Contracaecum sp. in the lakes of Pirassununga, state of São Paulo, Brazil. BENIGNO et al. (2012) estimated prevalence rates of 95.19 and $53.84 \%$ for larvae of Contracaecum sp. and Eustrongylides sp., respectively, in $H$. aff. malabaricus in the state of Pará, Brazil.

TAKEMOTO et al. (2009) identified Paracapillaria piscicola, Procamallanus (Procamallanus) peraccuratus, Procamallanus (Spirocamallanus) inopinatus, Goezia spinulosa, and Eustrongylides ignotus larvae and Contracaecum sp. in $H$. aff. malabaricus from the state of Paraná, Brazil, and PARAGUASSÚ; LUQUE (2007) identified Contracaecum sp. in H. aff. malabaricus in Rio de Janeiro, Brazil.

In humans with hypersensitivity, the ingestion of Anisakidae-infected fish (e.g., Anisakis simplex) may result in allergic reactions due to the presence of parasitic particles that act as antigens, triggering an immune response (MONTORO et al., 1997). Ingestion of endotoxins released by the parasite larvae in dead fish muscle has been reported to be toxic to humans (AUDICANA et al., 2002). The pathogenic potential of Contracaecum multipapillatum has been experimentally demonstrated under laboratory conditions by infecting mammals, thus, validating the need to inspect fish intended for human consumption (MUELLER et al., 2004).

The metacercariae of Digenea Carus, 1863 species that parasitize fish alter the tissues leading to the formation of nodules, resulting in carcass deformation, and thus, affecting its commercial value. In addition, infection by these parasites results in debilitation, making the host susceptible to predation by other piscivorous animals, which further act as a definitive host (PAVANELLI et al., 2002).

PARAGUASSÚ (2006) reported the occurrence of the parasite Ithyoclinostomum dimorphum in trahiras collected from the state of Rio de Janeiro. Similarly, RODRIGUES (2010) studied the parasites in trahiras and reported I. dimorphum from Rio Grande do Sul, Brazil, and the digenean trematode Diplostomum sp. from the Paraná River, São Paulo (LACERDA et al., 2013).

The metacercariae of some species of Clinostomidae can attach under the host's skin, forming nodules of light and relief coloring (DIAS et al., 2003); these metacercariae sometimes migrate to the eyes, causing blindness (SANTOS et al., 2002).

Monogenea Van Beneden, 1858 are mostly ectoparasites of fish, amphibians, and freshwater reptiles and have a direct evolutionary cycle. In fish, they are found mostly in the gills, nostrils, and on the exterior of the body (PAVANELLI et al., 2002).

CORRÊA et al. (2013b) detected monogenoids of Urocleidoides eremitus and Anacanthorus sp. in the gills of $H$. aff. malabaricus from Pirassununga, state of São Paulo.

After infection, the major clinical symptoms exhibited by the host are increased mucus production, reduction in body weight, and hemorrhage (PAVANELLI et al., 2002). The infected fish manifest compromised respiration as the monogenoids cause the lamellae to collapse, which may lead to mortality (MARTINS et al., 2000).

Acanthocephala Rudolphi, 1808 comprises helminths that possess a retractile proboscis with hooks that aid in fixation onto the lumen of the gastrointestinal tract of the host. Their biological cycle requires an arthropod and a vertebrate as the intermediate and definitive hosts, which harbor the larval and adult forms, respectively (THATCHER, 2006).

The acanthocephalan species Grasilisentis variabilis and Quadrigyrus brasiliensis were discovered in the Amazon region and Quadrigyrus torquatus in the regions of Mato Grosso, Brazil (THATCHER, 2006). ROSIM et al. (2005) were the first ones to report Quadrigyrus machadoi from $H$. aff. malabaricus collected from a pond in Aguaí, state of São Paulo, and TAKEMOTO et al. (2009) identified Q. machadoi in $H$. aff. malabaricus in the floodplain of the Upper Paraná River, Brazil. 
Some acanthocephalan species are zoonotic and have been studied because of their importance in human health (TANTALEÁN et al., 2005).

For completion of the biological cycle of members of Pentastomida Diesing, 1836, two hosts are required — one intermediate and one definitive. Fish act as the intermediate hosts for the larvae, while the adult cycle of the parasites is completed in the respiratory tract of reptiles (THATCHER, 2006). Specimens of Sebekia oxycephala were obtained from trahira (TAKEMOTO et al., 2009) collected from the Upper Paraná River.

Glochidium (Bivalvia Linnaeus, 1758), a larval stage of bivalve mollusks, usually acts as a temporary fish parasite. The larvae attach to the gill cavity, fins, or external surface of the body, forming nodules at the fixation site, in which it continues its biological cycle until they become adults (ARAÚJO, 2001).

BONETTO (1954) described a glochid from a Hyriidae species collected from Paraná River parasitizing the posterior tip of a branchial filament of $H$. aff. malabaricus.
The presence of parasitic helminths in fish is a common occurrence in the aquatic habitat. The environmental conditions determine the developmental cycle of these parasites, which usually present a seasonal variation in infection rates, with an increase in parasitic load in the hotter months (June to September) and a decrease in the colder months (December to March) in northern Brazil. Since most of the parasites found in Hoplias are pathogenic and can be transmitted to other hosts (EIRAS, 1994), knowledge of the parasitic infection in this fish is essential.

The evaluation of parasites of trahira is of utmost significance to public health, since the fish can harbor zoonotic parasites that can cause health issues in humans. Furthermore supervision of inspection and surveillance (BRASIL, 1952) need to be intensified. It is paramount that people be instructed to consume roasted or cooked fish. If consumption of raw fish is desired, it is recommended that the fish is frozen at $-20^{\circ} \mathrm{C}$ for one week to inactivate any potentially zoonotic parasites (EDUARDO et al., 2005).

Currently available information on the parasitic classes that affect fishes is limited, and further research is necessary. REFERENCES

\begin{abstract}
ALMEIDA, S.C. Aspectos ecológicos dos endohelmintos parasitos de Hoplias malabaricus (Bloch, 1794) (Osteichthyes - Erythrinidae) do alto rio Paraná, região de Porto Rico, Paraná, Brasil. 49 f. Dissertation (Mestrado) - Universidade Estadual de Maringá, Maringá, 1998.
\end{abstract}

ARAÚJO, C.M. Biologia reprodutiva do berbigão Anomalocardia brasiliana (Mollusca: Bivalvia, Veneridae) na Reserva Extrativista Marinha do Pirajubaé(REMAPI), Estado de Santa Catarina. 2001.203p. Thesis (Doutorado) - Universidade de São Paulo, São Paulo, 2001.

AUDICANA, M.T.; ANSOTEGUI, I.J.; DE CORRES, L.F.; KENNEDY, M.W. Anisakis simplex: dangerous - dead and alive? Trends in Parasitology, v.18, n.1, p.20-25, 2002. Available from: <http://www.cell. com/trends/parasitology/pdf/S1471-4922(01)02152-3. pdf>. Accessed on: Feb. 1, 2016.

BARROS, L.A.; MORAES FILHO J.; OLIVEIRA, R.L. Larvas de nematoides de importância zoonótica encontradas em traíras (Hoplias malabaricus Bloch, 1794) no município de Santo Antonio do Leverger, MT. Arquivo Brasileiro de Medicina Veterinária e Zootecnia, v.59, n.2, p.533-535, 2007. Available from: <http://www.scielo. br/pdf/abmvz/v59n2/42.pdf>. Accessed on: Feb. 1, 2016.

BENIGNO, R.N.; CLEMENTE, S.C.; MATOS, E.R.; PINTO, R.M.; GOMES, D.C.; KNOFF, M. Nematodes in Hoplerytrinus unitaeniatus, Hoplias malabaricus and Pygocentrus nattereri (pisces characiformes) in Marajó Island, Brazil. Revista Brasileira de Parasitologia Veterinária, v.21, n.2, p.165-170, 2012. Available from: <http://www.ncbi. nlm.nih.gov/pubmed/22832760>. Accessed on: Feb. 1, 2016.
BONETTO, A.A. Nayades del Rio Paraná: el género Diplodon en el biotopo isleño del Paraná medio y inferior. Publicación Técnica. Santa Fé: Secretaria de Agricultura, Ganaderia y Industrias, 1954. v. 62. p.1-56.

BRASIL. Regulamento da Inspeção Industrial e Sanitária de Produtos de Origem Animal (RIISPOA). Decreto no 30.691, de 29 de março de 1952. Diário Oficial da União, Cap.VI, Seção I, art.438-445, p.71-73, 1952. Available from: <http://www. planalto.gov.br/ccivil_03/decreto/1950-1969/d30691.htm>. Accessed on: Feb. 23, 2016.

CORREAA, L.L.; KARLING, L.C.; TAKEMOTO, R.M.; CECCARELLI, P.S.; UETA, M.T. Hematological alterations caused by high intensity of L3 larvae of Contracaecum sp. Railliet \&amp; Henry, 1912 (Nematoda, Anisakidae) in the stomach of Hoplias malabaricus in lakes in Pirassununga, São Paulo. Parasitology Research, v. 112 , n.8, p.2783-2789, 2013a. Available from: <http://link.springer. com/article/10.1007\%2FsO0436-013-3446-8>. Accessed on: Mar., 2014. doi: 10.1007/s00436-013-3446-8.

CORRÊA, L.L.; KARLING, L.C.; TAKEMOTO, R.M.; CECCARELLI, P.S.; UETA, M.T. Hematological parameters of Hoplias malabaricus (Characiformes: Erythrinidae) parasitized by Monogenea in lagoons in Pirassununga, Brazil. Revista Brasileira de Parasitologia Veterinária, v.22, n.4, p.457462, 2013 b. Available from: <http://www.scielo.br/scielo. php?pid=S 1984-29612013000400457\&script $=$ sci_

arttext>. Accessed on: Mar. 22, 2014. doi: 10.1590/ S1984-29612013000400003. 
DIAS, M.L.G.G.; EIRAS, J.C.; MACHADO, M.H.; SOUZA, G.T.R.; PAVANELLI, G.C. The life cycle of Clinostomum complanatum Rudolphi, 1814 (Digenea: Clinostomidae), on the foodplain of the high Paraná River, Brazil. Parasitology Research, v.89, p.506508, 2003. Available from: <https://www.ncbi.nlm.nih.gov/ pubmed/12658465>. Accessed on: Mar. 20, 2015.

EDUARDO, M.B.P.; SAMPAIO, J.L.M.; SUSUKI, E.; CÉSAR, M.L.V.S.; GONÇALVES, E.M.N.; CASTILHO, V.L.P.; ALBUQUERQUE, S.M.S.R.; PAVANELLO, E.I.; VIGILATO, M.A.N.; LÍRIO, V.S.; MANTESSO, I.S.; ZENEBON, O.; MARSIGLIA, D.A.P.; ATUI, M.B.; RODRIGUES, S.M.; RODRIGUES, R.M.M.S.; TORRES, D.M.A.G.V.; LATORRE, W.C.; FORTALEZA, C.M.C.B. Investigação epidemiológica do surto de difilobotríase, São Paulo, maio de 2005. Boletim Epidemiológico Paulista, São Paulo, v.17, n.17, p.1-12, maio 2005. Available from: <https://www.researchgate.net/publication/284888014_ Investigacao_epidemiologica_do_surto_de_difilobotriase_Sao_ Paulo_maio_de_2005>.Accessed on: Feb. 23, 2016.

EIRAS, J.C. A importância econômica de parasitos de peixes. Higiene Alimentar, São Paulo, v.8, n.31, 1994.

EMMEL, V.E.; INAMINE, E.; SECCHIII, C.; BRODT, T.C.; AMARO, M.C.O.; CANTARELLI, V.V.; SPALDING, S. Diphyllobothrium latum: relato de caso no Brasil. Revista da Sociedade Brasileira de Medicina Tropical, v.39, n.1, p.82-84, 2006. Available from: <http://www.scielo.br/scielo.php?script=sci_arttext\&pi $d=$ S0037-86822006000100017>. Accessed on: Aug. 25, 2013. DOI: $10.1590 /$ S0037-86822006000100017.

KIM, S.G.; JO, Y.J.; PARK, Y.S.; KIM, S.H.; SONG, M.H.; LEE, H.H.; KIM, J.S.; RYOU, J.W.; JOO, J.E.; KIM, D.H. Four Cases of Gastric Submucosal Mass Suspected as Anisarkisis. Korean Journal of Parasitology, v.44, n. 1, p.81-86, 2006. Available from: <http:// www.ncbi.nlm.nih.gov/pmc/articles/PMC2532642/>. Accessed on: May 27, 2012.

LACERDA, A.C.; TAKEMOTO, R.M.; POULIN, R.; PAVANELLI, G.C. Parasites of the fish Cichla piquiti (Cichlidae) in native and invaded Brazilian basins: release not from the enemy, but from its effects. Parasitology Research, v. 112, n. 1, p.279-288, 2013. Available from: <http://link.springer.com/article/10.1007\%2Fs00436012-3135-z>. Accessed on: Feb. 24, 2014. DOI: 10.1007/ s00436-012-3135-z.

LLAGUNO, M.M.; CORTEZ-ESCALANTE, J.; WAIKAGUL, J.; FALEIROS, A.C.G.; CHAGAS, F.D.; CASTRO, C. Diphyllobothrium latum infection in a nonendemic country: case report. Revista da Sociedade Brasileira de Medicina Tropical, v.41, n.3, p.301-303, 2008. Available from: $<$ http://www.scielo.br/scielo.php?script=sci_art text\&pid=S0037-86822008000300015>. Accessed on: Oct. 22 2013. DOI: 10.1590/S0037-86822008000300015.

LUQUE, J.L. Biologia, Epidemiologia e Controle de Parasitos de Peixes. Revista Brasileira de Parasitologia Veterinária, v.13, p.161-165, supl.1, 2004. Available from: <http://www.ufrrj. br/laboratorio/parasitologia/arquivos/publicacao/48_LIVRO. pdf >. Accessed on: Aug. 10, 2010.

MARTINS, M.L.; MORAES, F.R.; FUJIMOTO, R.Y.; ONAKA, E.M.; NOMURA, D.T.; SILVA, C.A.H.; SCHALCH, S.H.C. Parasitic infections in cultivated freshwater fishes a survey of diagnosticated cases from 1993 to 1998. Revista Brasileira de Parasitologia Veterinária, v.9, n.1, p.23-28, 2000. Available from: <http://www.rbpv.ufrrj. br/documentos/912000/c9123_28.pdf>. Accessed on: Sept. 22, 2011.

MONTENEGRO, A.K.A.; VIEIRA, A.C.B.; CARDOSO, M.M.L.; SOUZA, J.E.R.T.; CRISPIM, M.C. Piscivory by Hoplias aff. malabaricus (Bloch, 1794): a question of prey availability? Acta Limnologica Brasiliensia, v.25, n. 1, p.68-78, 2013. Available from: <http://www.scielo. br/pdf/alb/v25n1/a08v25n1.pdf >. Accessed on: May 3, 2014.

MONTORO, A.; PERTEGUER, M.J.; CHIVATO, T.; LAGUNA, R.; CUÉLLAR, C. Recidivuous acute urticaria caused by Anisakis simplex. Allergy, v.52, n.10, p.985-991, 1997. Available from: <http:// onlinelibrary.wiley.com/doi/10.1111/j.1398-9995.1997. tb02418.x/pdf>. Accessed on: Aug. 12, 2012.

MULLER, M.I.; MADI, R.R.; UETA, M.T. Fauna helmíntica de Hoplias malabaricus (Bloch, 1794) nos tanques da fazenda das pedras. In: ASSOCIAÇÃO BRASILEIRA DE PATOLOGISTAS DE ORGANISMOS AQUÁTICOS, 8., 2004, Campinas. Anais... Laguna: EMBRAPOA, 2004. v.1. p.34.

NOVAES, J.L.; CARVALHO, E.D. Population structure and stock assessment of Hoplias malabaricus (Characiformes: Erythrinidae) caught by artisanal fishermen in river-reservoir transition area in Brazil. Revista de Biologia Tropical, v.59, n.1, p.7183, 2011 . Available from: <https://repositorio.unesp.br/ handle/1 1449/18582>. Accessed on: Feb. 2, 2015.

PARAGUASSÚ, A.R. Composição e estrutura das comunidades de metazoários parasitos de sete espécies de peixes do reservatório de Lajes, Estado do Rio de Janeiro, Brasil. 11 pp. Thesis (Doutorado em Ciências Veterinárias) - Pós-Graduação em Ciências Veterinárias, Instituto de Veterinária, Universidade Federal Rural do Rio de Janeiro, Rio de Janeiro, 2006.

PARAGUASSÚ, A.R.; LUQUE, J.L. Metazoários Parasitos de Seis Espécies de Peixes do Reservatório de Lajes, Estado do Rio de Janeiro, Brasil. Revista Brasileira de Parasitologia Veterinária, v.16, n.3, p.121-128, 2007. Available from: <http://www.scielo.br/ pdf/rbpv/v16n3/aO2v16n3.pdf>. Accessed on: Feb. 2, 2016.

PAVANELLI, G.C.; EIRAS, J.C.; TAKEMOTO, R.M. Doenças de Peixes: Profilaxia, Diagnóstico e Tratamento. 2. ed. Maringá: Eduem, 2002. 305p.

RODRIGUES, A.P. Helmintos parasitos de Hoplias malabaricus (Ostheichtyes: Erytrinidae) comercializados na região sul do Rio Grande do Sul. 57p. Dissertation (Mestrado em Ciências) Universidade Federal de Pelotas, Pelotas, 2010.

ROSIM, D.F.; CECCARELLI, P.S.; SILVA-SOUZA, A.T. Parasitismo de Hoplias malabaricus (Block, 1974) (Characiformes, Erythrinidae) por Quadrigyrus machadoiFabio, 1983 (Eoacanthocephala, Quadrigyridae) de uma lagoa de Aguaí, Estado de São Paulo, Brasil. Revista Brasileira de Parasitologia Veterinária, v.14, n.4, p.147-153, 2005. Available from: <http://www.cbpv.org.br/rbpv/documentos/1442005/ c144147_153.pdf>. Accessed on: Jan. 1, 2016.

SAMPAIO, J.L.M.; ANDRADE, V.P.; LUCAS, M.C.; FUNG, L.; GAGLIARDI, S.M.B.; SANTOS, S.R.P.; MENDES, C.M.F.; EDUARDO, M.B.D.P.; DICK, T. Diphyllobothriasis, Brazil. Emerging Infectious Diseases, 2005. Available from: <https://www.ncbi.nlm.nih.gov/ pmc/articles/PMC3366747/pdf/05-0377.pdf> . Accessed on: Feb. 4, 2016. 
SANTOS, F.L.N.; FARO, L.B. The first Confirmed Case of Diphyllobothrium latum in Brazil. Memorias do Instituto Oswaldo Cruz, v.100, n.6, p.685-686, 2005. Available from: <http://www.scielo. br/scielo.php?pid=S0074-02762005000600013\&script $=$ sci arttext>. Accessed on: Aug. 18, 2012. DOI: 10.1590/ S0074-02762005000600013.

SANTOS, R.S.; PIMENTA, F.D.A.; MARTINS, M.L.; TAKAHASHI, H.K.; MARENGONI, N.G. Metacercárias de Diplostomum (Austrodiplostomum) compactum Lutz, 1928 (Digenea: Diplostomidae) em peixes do rio Paraná, Brasil. Prevalência, sazonalidade e intensidade de infecção. Acta Scientiarum, v.24, n.2, p.475-480, 2002. Available from: <http://www.periodicos.uem.br/ojs/index.php/ActaSciBiolSci/ article/view/2350/2291 >. Accessed on: Nov. 10, 2012.
TAKEMOTO, R.M.; PAVANELLI, G.C.; LIZAMA, M.A.P.; LACERDA, A.C.F.; YAMADA, F.H.; MOREIRA, L.H.A.; CESCHINI, T.L.; BELLAY, S. Diversity of parasites of fish from upper Paraná river floodplain, Brazil. Brazilian Journal of Biology, v.69, n.2, p.691-705, 2009. Available from: <http://www.scielo.br/pdf/bjb/v69n2sO/ v69n2sOa23.pdf >. Accessed on: Jun. 12, 2013.

TANTALEÁN, M.; SÁNCHEZ, L.; GÓMEZ, L.; HUIZA, A. Acantocéfalos del Peru. Revista Peruana de Biologia, v. 12, n. 1, p.83-92, 2005. Available from: <http://sisbib.unmsm.edu.pe/BVRevistas/biologia/ v12_n1/pdf/v12n1a06.pdf>. Accessed on: Sept. 13, 2012.

THATCHER, V.E. Aquatic Biodiversity in Latin America: Amazon Fish Parasites. 2. ed. Sofia: Pensoft, 2006. v.1. 496p. 